\title{
The Quantity Theory of Money
}

\section{Yi Wen}

$\mathrm{T}$ he quantity theory of money (QTM) asserts that aggregate prices $(P)$ and total money supply $(M)$ are related according to the equation $P=V M / Y$, where $Y$ is real output and $V$ is velocity of money. With lower-case letters denoting percentage changes (growth rates), the QTM can be expressed as $p=v+m-y$, with $p$ as the rate of inflation and $y, v$, and $m$ as growth rates of output, velocity, and money stock, respectively. A central implication of the QTM is that a given change in the rate of money growth induces an equal change in the inflation rate, prompting Milton Friedman to claim that "inflation is always and everywhere a monetary phenomenon." ${ }^{1}$

A crucial assumption behind this claim is that the velocity of money or its growth rate is constant and money growth has no effect on real GDP growth-at least at a sufficiently long horizon. In fact, many empirical studies of the QTM treat the velocity of money or its growth rate as constant. However, postwar U.S. data suggest the velocity of money is far from constant.

Instead of assuming the velocity of money or its growth rate is a constant, we can use the QTM equation, $v=p+y-m$, to allow the changes in velocity to be dictated directly by three sources: inflation, output growth, and money growth. The dynamic interactions among these three variables can be captured by econometric analysis. ${ }^{2}$ In this way, the dynamics of velocity are not restricted a priori. And such analysis shows that money growth and inflation are indeed highly correlated in the very long run. The chart shows the correlation between money growth and inflation across different horizons (or frequencies), ${ }^{3}$ which reaches 0.85 in the long run (at frequency zero) and never exceeds 0.4 at horizons equal to or shorter than the business cycle (about 2 to 8 years). The chart also may suggest that Friedman is right: At least in the long run, changes in inflation and changes in money growth are closely related.

However, further analysis ${ }^{4}$ shows that the close long-run relationship between inflation and money growth may not necessarily be driven by purely monetary forces, but rather by forces such as permanent movements in GDP and nonmonetary shocks. For example, in analyses that assume money growth shocks do not affect velocity and output growth in the long run (à la Friedman), about 18 percent of the long- run movement of inflation at frequency zero is attributable to money growth shocks; the remaining 82 percent is due to shocks that can have permanent long-run effects on output and the velocity of money.

This result suggests that endogenous monetary policy may have allowed non-monetary shocks to have a stronger effect on inflation than autonomous movement in money supply. Therefore, while the close long-run link between money growth and inflation supports Friedman's proposition, the significance of this link for monetary policy requires further investigation of the underlying factors that drive inflation and money growth.

\footnotetext{
${ }^{1}$ Friedman, Milton. “The Counter-Revolution in Monetary Theory." Wincott Memorial Lecture, London, September 16, 1970.

2 The analysis uses spectral methods; see Sargent, Thomas. Macroeconomic Theory. Academic Press, 1987.

${ }^{3}$ The $\mathrm{x}$ axis indicates the frequency or inverted horizon of changes in inflation and money growth. E.g., frequency 0.0 means the horizon for a change is infinite periods; frequency 0.5 means the horizon for a change is 2 periods. The data are quarterly, so one period is a quarter. The vertical bars represent a business-cycle horizon from 2 to 10 years. The y axis indicates the correlation between money and inflation at each possible horizon, from infinite quarters to 2 quarters. The shortest horizon is 2 periods.

4 The analysis uses variance decomposition methods in the frequency domain; see Wen, Yi. "The Business Cycle Effects of Christmas." Journal of Monetary Economics, 2002, 49, pp. 1289-314.
}

\section{Money-Inflation Correlation}

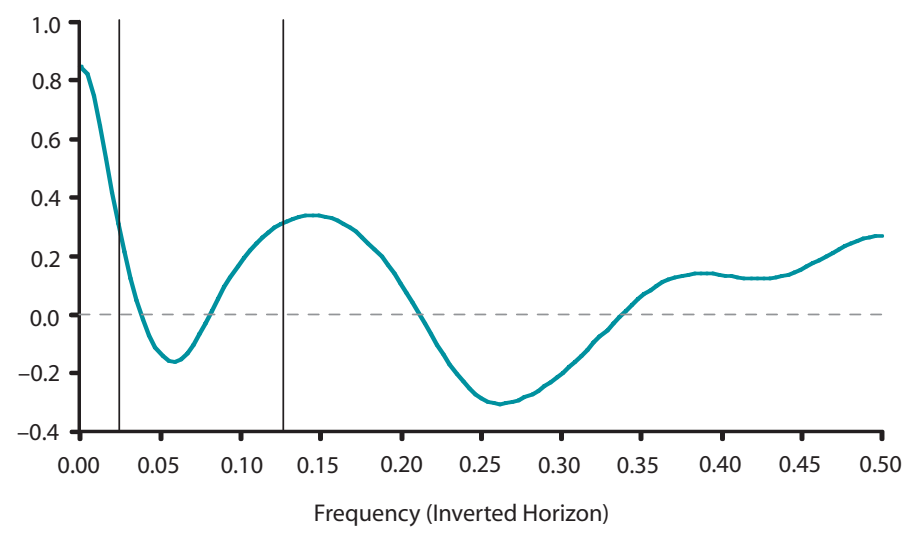

